\title{
Expression of Interleukin 13 Receptor in Glioma and Renal Cell Carcinoma: IL13R $\alpha 2$ as a Decoy Receptor for IL13
}

\author{
Jérôme Bernard, Dominique Treton, Claudine Vermot-Desroches, Christine Boden, \\ Philippe Horellou, Eric Angevin, Pierre Galanaud, John Wijdenes, and \\ Yolande Richard
}

\author{
INSERM U 131 (JB, DT, CB, PG, YR) and EMI 00-20 (PH), Institut Paris-Sud sur les Cytokines, Clamart; Diaclone \\ Research (CV-D, JW), Besançon; and Unité d'Immunothérapie (EA), Institut Gustave Roussy, Villejuif, France
}

\begin{abstract}
SUMMARY: Glioma and renal cell carcinoma (RCC) cells express high affinity interleukin 13 (IL13) binding sites, but only RCC cell proliferation was inhibited by IL13. Both of these two cell types are IL2-receptor $\gamma \mathrm{c}$ chain-negative. We thus used these cell models to investigate the patterns of expression of IL13R $\alpha 1$, IL13R $\alpha 2$, and IL4R $\alpha$ chains and the role of IL13R $\alpha 2$ in the response to IL13. Using new specific antibodies and flow cytometry, we observed a similar surface expression of IL4R $\alpha$ and IL13R $\alpha 1$ chains in most RCC and glioma cells, whereas IL13R $\alpha 2$ was only present on five of six glioma cell lines. In all glioma cell lines, the amount of IL13R $\alpha 2$ expression was 10 to 30 times higher than that of the two other chains. Although there was no surface or intracellular expression of IL13R $\alpha 2$, its mRNA was detected in three of seven RCC cell lines. The expression on RCC cells of IL13R $\alpha 2$ mRNA and/or that of high-affinity IL13 binding sites is not sufficient to predict IL13R $\alpha 2$ protein expression. Blocking experiments showed that IL4 and IL13 strongly inhibited RCC cell proliferation through a unique receptor composed of IL4R $\alpha$ and IL13R $\alpha 1$ chains. Using RCC cells stably transfected with IL13R $\alpha 2$ cDNA, we showed that the overexpression of IL13R $\alpha 2$ decreased the response to IL13 but not that to IL4. Our results demonstrate that IL13R $\alpha 2$ acts as a decoy receptor for IL13 and that it may exert a tight regulation of IL13 activity without impairing the IL4 response of the same cell target. (Lab Invest 2001, $81: 1223-1231)$.
\end{abstract}

\begin{abstract}
nterleukin 13 (IL13) is an immune regulatory cyto1 kine that is produced predominantly by activated Th2 T cells, mast cells, and basophils. It shares many biological properties with IL4 (Zurawski and de Vries, 1994). However, in contrast to IL4, IL13 has no direct effect on $\mathrm{T}$ cells. In addition to its major role in inflammatory diseases (Wills-Karp et al, 1998), IL13 may play a prominent role in tumor growth; binding experiments show that high-affinity IL13 receptors (IL13R) are abundant in various human carcinoma and glioma cell lines (Debinski et al, 1999; Maini et al, 1997; Murata et al, 1997b; Obiri et al, 1995; Serve et al, 1996). The cell growth of renal and breast carcinoma cells, but not that of glioma cells, is inhibited by IL13, although all express high-affinity IL13R (Debinski et al, 1995; Obiri et al, 1996; Serve et al, 1996). Receptor cross-competition studies of hematopoietic cells have suggested that receptors for IL4 and IL13 share a common component, the IL $4 \mathrm{R} \alpha$ chain (Tony et
\end{abstract}

Received May 3, 2001.

This work was supported by grants from Association pour la Recherche sur le Cancer (ARC), the Institut National de la Santé et de la Recherche Médicale (INSERM), the Association Claude Bernard, and the Université Paris-Sud (Paris XI). JB is supported by a fellowship from the ARC.

Address reprint requests to: Dr. Yolande Richard, INSERM U131, 32 rue des Carnets, 92140 Clamart, France. E-mail: yolande. richard@inserm.ipsc.u-psud.fr al, 1994; Zurawski et al, 1995). This was confirmed by biochemical studies showing that IL13R triggering induces the recruitment and tyrosine phosphorylation of IL4R $\alpha$ (Rolling et al, 1996; Smerz-Bertling and Duschl, 1995; Welham et al, 1995). The genes for two IL13R $\alpha$ chains have been cloned from mice and humans. The IL13R $\alpha 1$ chain alone specifically binds IL13 with a low affinity. In association with the IL $4 R \alpha$ chain, it forms a high-affinity IL13R (Aman et al, 1996; Gauchat et al, 1997; Hilton et al, 1996; Miloux et al, 1997), and, thus, IL13R $\alpha 1$ is essential for IL4/IL13 mediating effects (Murata et al, 1998; Orchansky et al, 1997). The second IL13R $\alpha$ chain, termed IL13R $\alpha 2$, binds to IL13 with higher affinity than does IL13R $\alpha 1$. Coexpression of IL13R $\alpha 2$ with IL $4 \mathrm{R} \alpha$ does not allow the response to IL13, and its coexpression with the IL4R $\alpha / \operatorname{IL} 13 R \alpha 1$ complex does not modify the affinity of this complex for IL13 (Caput et al, 1996; Donaldson et al, 1998). Binding experiments and mRNA expression analysis have led to the description of four types of IL13R differently expressed by various cell types (Murata et al, 1997a; Obiri et al, 1997; Vita et al, 1995). However, little information is available regarding the biological relevance of these different receptor types.

To better characterize the IL13R expression and function in tumor cells, we studied seven renal cell carcinoma (RCC) and six glioma cell lines for IL13R $\alpha 1$, IL13R $\alpha 2$, and IL4R $\alpha$ subunit, mRNA and protein. Us- 
ing new specific antibodies and flow cytometry, we found that (a) unlike glioma cells, RCC do not express IL13R $\alpha 2$ chain, whereas IL13R $\alpha 2$ mRNA was present in three of the seven RCC cell lines tested; (b) RCC, but not glioma cell proliferation, is inhibited by IL13 and IL4; (c) the effects of IL13 and IL4 on RCC are mediated through a common receptor including the IL4R $\alpha$ chain; and (d) overexpression of IL13R $\alpha 2$ in stably transfected RCC cells specifically inhibits the IL13-mediated effect, demonstrating that IL13R $\alpha 2$ acts as a "decoy target" for IL13.

\section{Results}

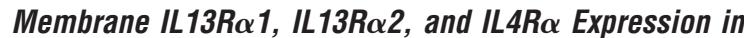 Glioma and RCC Cell Lines}

We studied the surface expression of IL13R $\alpha 1$, IL13R $\alpha 2, \operatorname{IL} 4 \mathrm{R} \alpha$, and $\gamma \mathrm{c}$ chains by flow cytometry (Table 1). None of the glioma and RCC cell lines expressed the $\gamma \mathrm{c}$ chain. IL13R $\alpha 2$ was expressed in all glioma cell lines except the cell line T98G, but in none of the RCC cell lines. IL13R $\alpha 1$ was present in all glioma and RCC cell lines, and IL4R $\alpha$, which was present on all RCC cell lines, was also detected in four of six glioma cell lines (SF126, SKMG12, U399MG, and T98G). The glioma cell lines (Fig. 1) carried more IL13R $\alpha 2$ (mean fluorescence intensity [MFI] above 700) than IL13R $\alpha 1$ (MFI ranging from 20 to 40) or IL4R $\alpha$ (MFI ranging from 80 to 260). In all cases, the intensity of IL4R $\alpha$ staining was stronger than that of IL13R $\alpha 1$.

\section{Expression of IL13R $\alpha 1$, IL13R $\alpha 2$, and IL4R $\alpha$ mRNA in Glioma and RCC Cell Lines}

Because most RCC have high-affinity IL13 binding sites and contain IL13R $\alpha 2$ mRNA, Murata et al (1997a)

Table 1. IL13R Subunits at the Cell Surface of Various Tumor Cell Lines

\begin{tabular}{lcccc}
\hline & \multicolumn{4}{c}{ IL13R subunits $^{a}$} \\
\cline { 2 - 5 } Cell lines & IL13R $\alpha 2$ & IL13R $\alpha 1$ & IL4R $\alpha$ & $\gamma \mathrm{C}$ \\
\hline Glioma & & & & \\
SF126 & +++ & + & ++ & - \\
SKMG12 & +++ & + & ++ & - \\
U399MG & +++ & + & ++ & - \\
U373MG & +++ & + & - & - \\
SNB19 & +++ & + & - & - \\
T98G & - & + & ++ & - \\
RCC & & & & \\
ACHN & - & + & ++ & - \\
A704 & - & + & ++ & - \\
RCC1 & - & + & ++ & - \\
RCC17 & - & + & ++ & - \\
RCC40 & - & + & ++ & - \\
RCC42 & - & + & ++ & - \\
RCC47 & - & + & ++ & - \\
\hline
\end{tabular}

RCC, renal cell carcinoma.

${ }^{a}$ Staining was evaluated as the mean fluorescence intensity as described in "Materials and Methods": $(-)$ negative, $(+)$ positive, $(++)$ strongly positive and $(+++)$ very strongly positive.
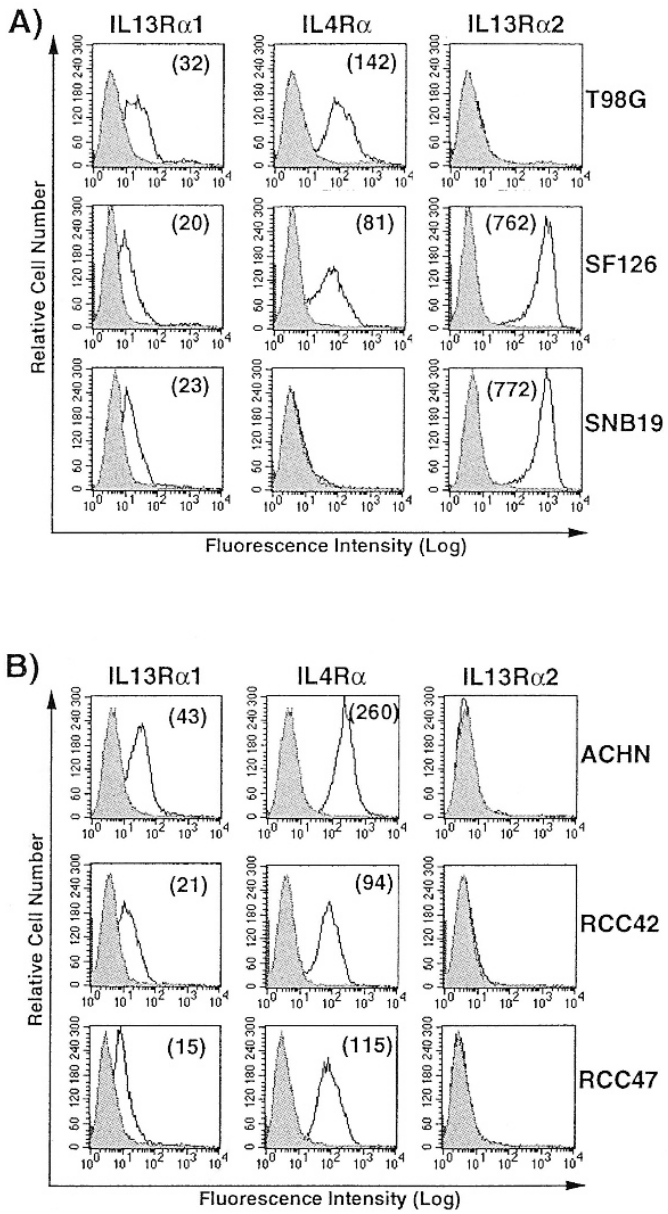

Figure 1.

Representative IL $13 \mathrm{R} \alpha 1, \mathrm{IL} 13 \mathrm{R} \alpha 2$, and IL4R $\alpha$ surface immunoreactivity in glioma and renal cell carcinoma (RCC) cells. Glioma (A) and RCC (B) cells were stained with mouse monoclonal antibodies (MoAbs) raised against IL $13 \mathrm{R} \alpha 1$, IL13R $\alpha 2$, and IL $4 \mathrm{R} \alpha$ chains and relevant controls (solid histogram), as described in "Materials and Methods." Results are given as mean fluorescence intensity (MFI) in brackets. Data are representative of five independent experiments.

concluded that RCC carry IL $13 \mathrm{R} \alpha 2$ protein at their surface. However, our results showed that RCC did not carry membrane IL $13 \mathrm{R} \alpha 2$ (mIL13R $\alpha 2)$. We, therefore, tested for the presence in RCC and glioma cell lines of IL4R $\alpha$ and IL $13 R \alpha$ chain transcripts by reverse transcription-polymerase chain reaction (RT-PCR) (Fig. 2). As expected from the presence of the proteins on the cell surface, IL13R $\alpha 1$ and IL4R $\alpha$ mRNAs were detected in all RCC cell lines. All RCC were devoid of mIL13R $\alpha 2$, but, surprisingly, IL13R $\alpha 2$ mRNA was detected in three of seven RCC cell lines. In glioma, the presence of the IL13R $\alpha 2$, IL13R $\alpha 1$, and IL4R $\alpha$ mRNAs correlated with the presence of the corresponding membrane proteins in most cases. However, the SNB19 cell line was devoid of IL4R $\alpha$ protein but contained the mRNA.

\section{IL13Ra2 Protein Is Detected in Lysates from Glioma but Not from RCC Cell Lines}

To test whether IL13R $\alpha 2$ mRNA leads to the production of intracellular IL13R $\alpha 2$ in RCC, IL13R $\alpha 2$ protein 

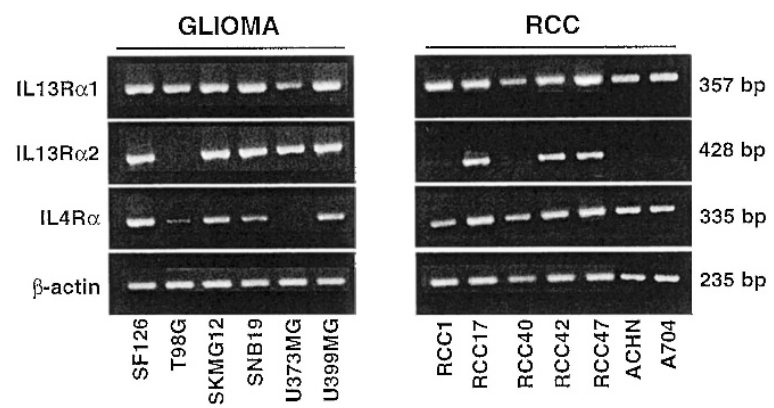

Figure 2.

IL13R $\alpha 1$, IL13R $\alpha 2$, and IL4R $\alpha$ transcripts in glioma and RCC cells. cDNA from each cell line was amplified as described in "Materials and Methods." Data are representative of three independent experiments.

was assayed by ELISA (Fig. 3). No IL13R $\alpha 2$ was detected in lysates from IGR-RCC17, 42, or 47, although they contained the transcript. As controls, we showed that IL13R $\alpha 2$ protein was detected in SNB19 and SF126 cell lysates $\left(\mathrm{mL} 13 \mathrm{R} \alpha 2^{+}\right)$but was absent from T98G and IGR-RCC1 lysates (mIL13R $\alpha 2^{-}$). Similarly, intracellular IL13R $\alpha 2$ protein was not detected in flow cytometry after permeabilization of RCC cells (data not shown). Thus, glioma, but not RCC, cells expressed IL13R $\alpha 2$ protein, whereas both cell types similarly expressed membrane IL4R $\alpha$ and IL13R $\alpha 1$.

\section{Glioma, but Not RCC, Cells Are Insensitive to IL4 and IL13}

To investigate the functional significance of IL13R expression, we compared $\left({ }^{3} \mathrm{H}\right)$-thymidine uptake in glioma and RCC cells cultured with or without IL4 or IL13. Because none of these cell lines produced the IL2R $\gamma$ chain (Table 1), IL2 was used as control. IL4 and IL13 inhibited the cellular proliferation of the T98G cell line by $20 \%$ (Fig. 4A). However, IL4 or IL13 had no effect on the proliferation of SNB19, SKMG12, SF126, U373MG, or U399MG cell lines (Fig. 4A and data not shown). In contrast to glioma cells, IL13 and IL4

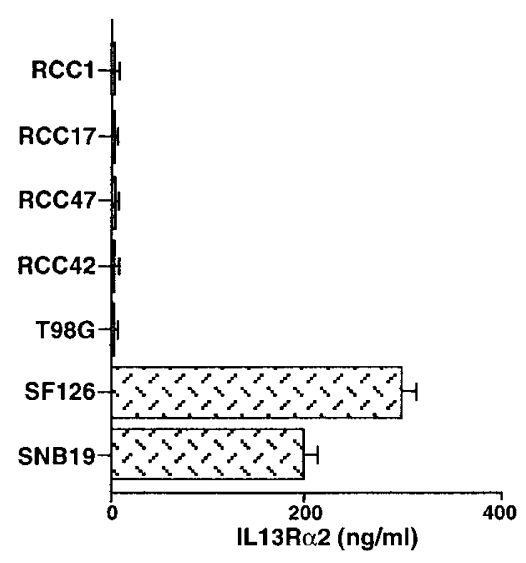

Figure 3.

IL13R $\alpha 2$ expression in lysates from glioma and RCC cells. Four hundredmicrogram aliquots of total cell lysates were assayed for IL13R $\alpha 2$ protein by ELISA as described in "Materials and Methods." Results are expressed as the mean concentration $(\mathrm{ng} / \mathrm{ml} \pm \mathrm{SD})$ of triplicate determinations. Data are representative of two independent experiments.
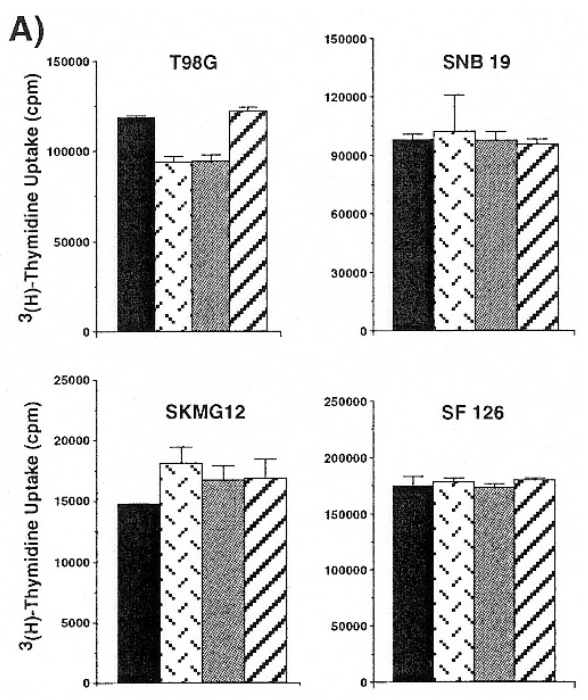

B)
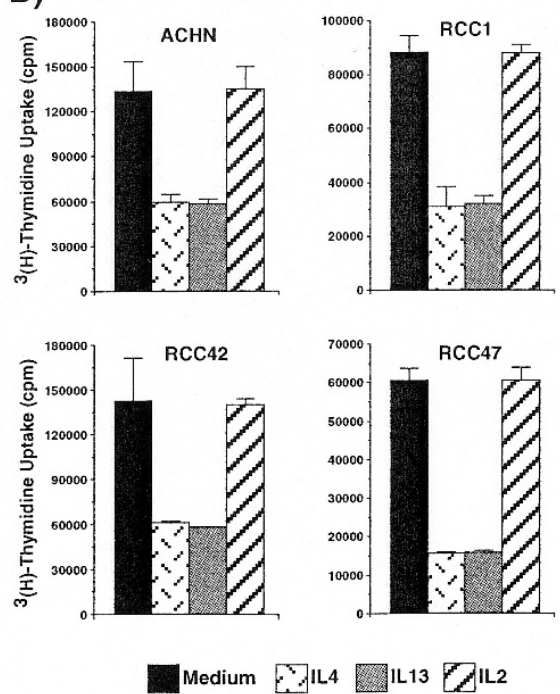

Figure 4.

Tumor cell proliferative response to IL4 and IL13 stimulation. Glioma cells (A) and RCC (B) were cultured with or without IL4 (20 ng/ml), IL13 $(20 \mathrm{ng} / \mathrm{ml})$, or IL2 $(20 \mathrm{ng} / \mathrm{ml})$ for 3 days, as described in "Materials and Methods." The proliferative response was measured by following $\left({ }^{3} \mathrm{H}\right)$-thymidine uptake during the last 12 hours of culture. Results are expressed in counts per minute $(\mathrm{cpm})$ (mean of triplicates $\pm \mathrm{sD}$ ). Data are representative of five independent experiments.

strongly inhibited cellular proliferation of all RCC cell lines (Fig. 4B and data not shown). Neither the cell proliferation of T98G nor that of RCC cells was affected by IL2 treatment. These data suggested that IL13R $\alpha 2$ expression is associated with the absence of the IL13-mediated proliferative response.

\section{IL13 Effects in RCC Are Mediated through the IL4R $\alpha$ Chain}

Recent studies indicate that IL $4 \mathrm{R} \alpha$ is a functional subunit of IL13R in transfected cells (Murata et al, 1998; Orchansky et al, 1997). To establish whether the growth inhibitory effects of IL4 and IL13 on RCC cells are mediated through a IL4R $\alpha / \operatorname{IL} 13 \mathrm{R} \alpha 1$ complex, we 
tested the effect of neutralizing antibody directed against human IL4R $\alpha$ chain. This anti-IL $4 \mathrm{R} \alpha$ antibody reversed the growth inhibition induced by IL4 and IL13, whereas a soluble IL13R $\alpha 2-\mathrm{Fc}$ fusion protein only antagonized the IL13-mediated effect (Fig. 5). These experiments demonstrate that, in contrast to a previous report (Obiri et al, 1996), IL4R $\alpha$ participates in the signaling complex used by IL13 in RCC cells.

\section{Modulation of IL13- but Not IL4-Mediated Effects by IL13R 22}

The absence of IL13-mediated response in all glioma cells, other than T98G which did not have a membrane IL13R $\alpha 2$ chain, suggested that IL13R $\alpha 2$ is responsible for this lack of response. To test this, we established stable transfectants of IL $13 R \alpha 2$ in the human renal adenocarcinoma cell line, ACHN. Two clones (27 and 28) produced large amounts of the IL $13 R \alpha 2$ chain as detected by flow cytometry (MFI 220 and 190 respectively), whereas the mock cells were negative (Fig. 6). Of note, the presence of IL13R $\alpha 2$ did not affect the expression of membranes IL13R $\alpha 1$ and IL4R $\alpha$ compared with mock cells.

We next examined the impact of the presence of IL13R $\alpha 2$ on the IL13- and IL4-induced inhibition of cell proliferation. The IL13- and IL4-mediated inhibition in mock-transfected cells was dose-dependent (Fig. 7). Maximum inhibition of these control cells was reached at $5 \mathrm{ng} / \mathrm{ml}$ for both cytokines and plateaued thereafter. In contrast, the overexpression of IL13R $\alpha 2$ in 27 and 28 cells reduced their ability to respond to suboptimal IL13 concentrations (up to $5 \mathrm{ng} / \mathrm{ml}$ ) but did not affect their response to IL4. In the presence of higher concentrations of IL13 $(10-20 \mathrm{ng} / \mathrm{ml})$, the proliferative response of 27 and 28 cells was inhibited as strongly as that of mock cells. These findings are consistent with IL13R $\alpha 2$ acting as a "decoy target" for IL13.

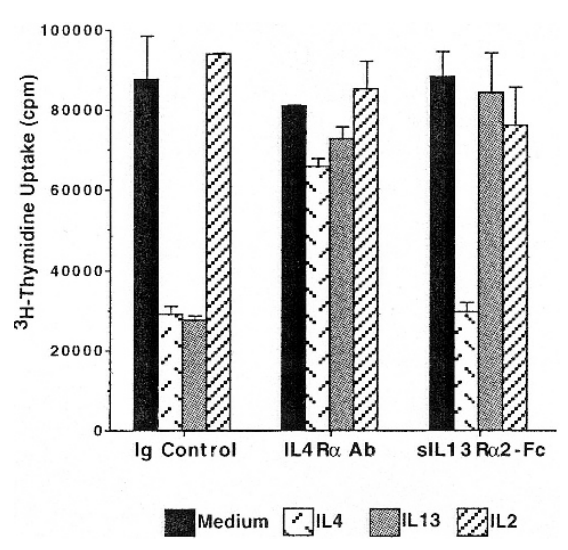

Figure 5.

Effects of anti-IL4R $\alpha$ antibody and SIL13R $\alpha 2$-Fc protein on IL4- and IL13mediated responses in RCC. The RCC cell line ACHN was cultured with or without IL4 $(20 \mathrm{ng} / \mathrm{ml})$, IL13 $(20 \mathrm{ng} / \mathrm{ml})$, or IL2 $(20 \mathrm{ng} / \mathrm{ml})$, and in the absence or the presence of anti-IL4R $\alpha$ antibody $(10 \mu \mathrm{g} / \mathrm{ml})$, mouse IgG isotype control $(10 \mu \mathrm{g} / \mathrm{ml})$, or sIL13R $\alpha 2-\mathrm{Fc}$ protein $(1 \mu \mathrm{g} / \mathrm{ml})$ for 3 days, as described in "Materials and Methods." Proliferative response was measured by following $\left({ }^{3} \mathrm{H}\right)$-thymidine uptake during the last 12 hours of culture. Results are expressed in counts per minute (cpm) (mean of triplicates $\pm \mathrm{sD}$ ). Data are representative of three independent experiments.

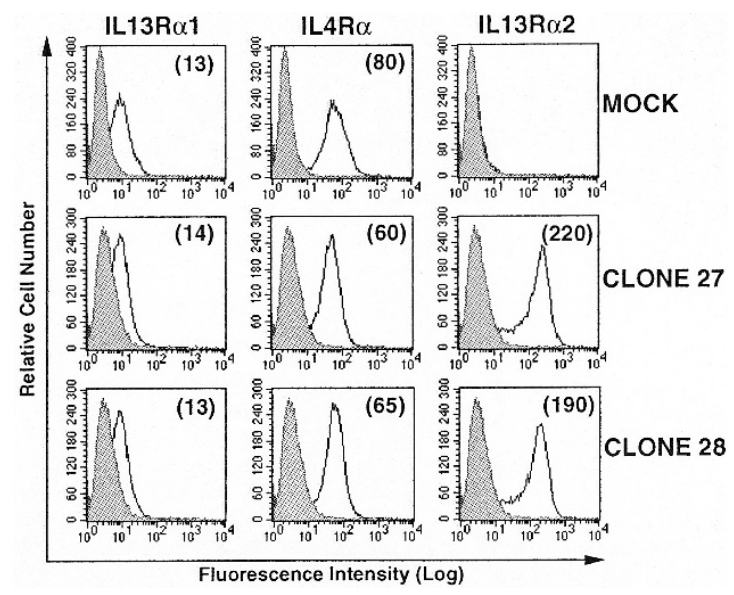

Figure 6.

IL13R $\alpha 2$ expression in stable transfectant. Stably transfected ACHN clones were obtained and stained with MoAbs raised against IL 13R $\alpha 1$, IL 13R $\alpha 2$, and IL4R $\alpha$ chains and relevant controls (solid histogram), as described in "Materials and Methods." Results are given as mean fluorescence intensity (MFI) in brackets. Data are representative of three independent experiments.

\section{Discussion}

Three potential components of human IL13R were identified, namely IL $13 \mathrm{R} \alpha 1$, IL $13 \mathrm{R} \alpha 2$, and IL $4 \mathrm{R} \alpha$. Although IL4R $\alpha$ is an essential component of functional IL13R, only IL13R $\alpha 1$ and IL13R $\alpha 2$ are able to bind IL13 specifically (Aman et al, 1996; Caput et al, 1996; Orchansky et al, 1997; Zurawski et al, 1995). The IL13R $\alpha 1 /$ IL $4 R \alpha$ complex is required for response to IL13, but the contribution of IL13R $\alpha 2$ chain to this response has not been elucidated and may vary according to the cell target. Primary monocytes and B lymphocytes express small amounts of high-affinity IL13R and large amounts of IL13R of low to intermediate affinity, (Zurawski and de Vries, 1994), whereas binding experiments show that most solid tumor cells mainly express high-affinity IL13R (Debinski et al, 1999; Maini et al, 1997; Murata et al, 1997b; Obiri et al, 1995; Serve et al, 1996). Despite the fact that both express high-affinity IL13 binding sites, glioma and RCC cells are differently sensitive to IL13 (Debinski et al, 1995; Obiri et al, 1996). This and the analysis of the mRNAs IL13R $\alpha 1$ and IL13R $\alpha 2$ suggested that these cell types have different functional IL13R configurations (Murata et al, 1997a). We studied membrane IL13R $\alpha 1$ and IL13R $\alpha 2$ proteins to characterize IL13R configurations better.

Using new specific antibodies and flow cytometry, we observed a similar surface expression of IL4R $\alpha$ and IL13R $\alpha 1$ chains in most RCC and glioma cell lines. In contrast, IL13R $\alpha 2$ was only present on glioma cells where it was 10 to 30 times more abundant than the two other chains. Our results agree with those of Joshi et al (2000) showing greater expression of IL13R $\alpha 2$ than IL4R $\alpha$ and IL $13 R \alpha 1$ chains in primary explants from gliomas. In agreement with the lack of IL13R $\alpha 2$ chain expression in T98G, Debinski et al (1995) have previously shown that this cell line only expresses 500 IL13 binding sites, whereas U373MG and SNB19, which highly express the IL $13 R \alpha 2$ chain, exhibit more 

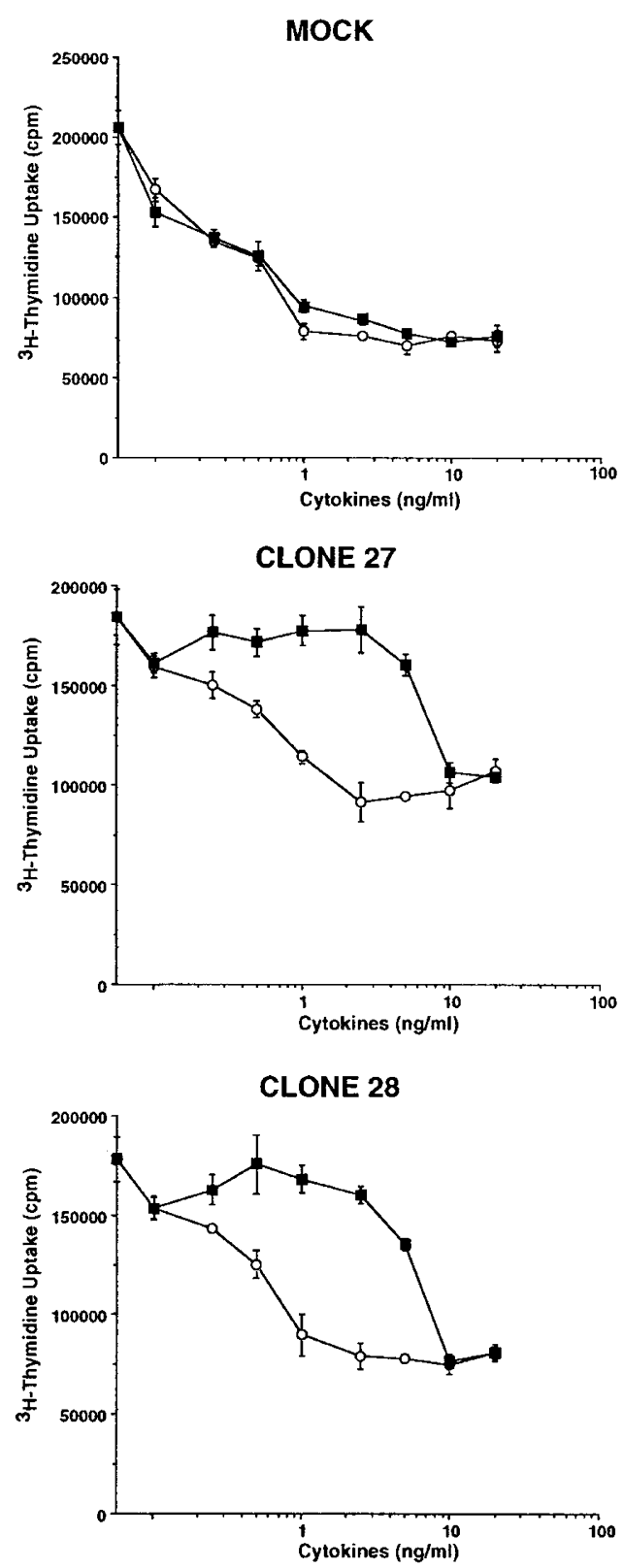

Figure 7.

Proliferative response to IL13 and IL4 stimulation of transfected cells. The ACHN-transfected cells expressing (clones 27 and 28) the IL13R $\alpha 2$ chain and mock-transfected cells were cultured with or without one of a series of concentrations of IL4 (black squares) or IL13 (open circles) for 3 days, as described in "Materials and Methods." The proliferative response was measured by following $\left({ }^{3} \mathrm{H}\right)$-thymidine uptake during last 12 hours of culture. Results are expressed in counts per minute (cpm) (mean of triplicates $\pm \mathrm{sD}$ ). Data are representative of three independent experiments.

than 16,000 IL13 binding sites. Although there was no surface IL13R $\alpha 2$ protein on RCC, its mRNA was detected in three of seven RCC, in agreement with previous reports (Murata et al, 1997a; Obiri et al, 1997). Like Kawakami et al (2000), we did not detect IL13R $\alpha 2$ at the cell surface of Caki-1 cells (not shown), a RCC cell line that contains the corresponding mRNA (Caput et al, 1996). Despite the presence of IL13R $\alpha 2$ mRNA, we failed to detect an intracellular form of IL13R $\alpha 2$ in RCC cells.
To assess whether IL13R was functional, we tested the proliferative responses of RCC and glioma cell lines to IL4 and IL13. Only the proliferation of one glioma cell line of six (T98G) was weakly inhibited by IL4 and IL13, whereas the growth of all RCC cell lines was strongly inhibited by both cytokines. Several studies have already reported that IL13 and IL4 were neither able to modulate cell proliferation nor signal transducer and activator of transcription (STAT)6 activation in glioma cells (Debinski et al, 1995, 1996; Liu et al, 2000a). In addition, we also found that IL13 and IL4 did not modulate the production of IL6 or IL8 in these glioma lines (data not shown). Thus, other than the T98G cell line, glioma cells seem to be unresponsive to IL4 and IL13. The lack of responsiveness to IL4 has been previously reported (Debinski et al, 1996) and seems a hallmark of the progression towards high grade tumors (Debinski et al, 1999). Although all cell lines used in the present study are classified as high grade glioma, express similar levels of epidermal growth factor-receptor (EGF-R) and insulin-like growth factor 1 receptor (IGF1-R), and produce similar levels of IL8 (data not shown), it remains possible that they correspond to different stages of tumor progression. The lack of responsiveness to IL4 is easily explained by the lack of IL4R $\alpha$ chain expression in the U373MG and SNB19 cell lines. In contrast, IL4R $\alpha$ and IL13R $\alpha 1$ chains are expressed by SF126, SKMG12, and U399MG cells, suggesting that defects in the IL4R cell signaling pathway occur in these cells. Accordingly, Liu et al (2000a) have described abnormal patterns of STAT6 phosphorylation in various glioma cells. Liu et al (2000b) have also shown that IL4 responsiveness in astrocytoma requires unmutated p53 and involves regulation of p21 (waf1/cip1) and p27 (Kip1) expression. Besides IL4R signaling impairments, the strong expression of IL13R $\alpha 2(680<\mathrm{MFI}<772)$ in SF126, SKMG12, and U399MG cells may induce the formation of nonfunctional, ligand-independent heterotrimeric receptors. In our IL13R $\alpha 2$-transfected clones, the expression of IL13R $\alpha 2$ is weaker than that in glioma (190 < MFI < 220), and, thus, IL4R, including or not including a IL13R $\alpha 2$ chain, may coexist, allowing a response to low doses of IL4. To verify whether IL13R $\alpha 2$ expression is also responsible for the lack of response to IL4 in glioma cells, we are currently testing an mRNA antisense strategy to "switch off" the IL13R $\alpha 2$ production in these cells. Alternatively, we would transfect the IL13R $\alpha 2$ chain in the T98G cell line or in IL4-sensitive low-grade astrocytoma (Liu at al, 2000a).

Blocking experiments showed that IL4 and IL13 exerted a strong inhibition of RCC cell proliferation through a unique receptor composed of the IL4R $\alpha$ and IL13R $\alpha 1$ chains. This was confirmed by the lack of additive effect of IL4 and IL13 on the growth of RCC cells (data not shown). Our results constrasted with those of Obiri et al (1996), who reported that IL13mediated effects on RCC cells are IL4R $\alpha$ independent. This discrepancy could be explained by the use of different anti-IL4R $\alpha$ antibodies that nevertheless exert a similar antagonistic activity on the IL13 
response of lymphoid cells. Thus, our results with RCC showed that the expression of IL13R $\alpha 2$ mRNA and/or that of high-affinity IL13 binding sites is not sufficient to predict IL13R $\alpha 2$ protein expression. Interestingly, we showed that IL13 is a potent inhibitor of cell proliferation of primary (IGR-RCC17, 40, and 42) and metastatic (IGR-RCC1) renal nonpapillary or papillary (IGR-RCC47) tumors.

Unlike that of IL $13 R \alpha 1$, the function of IL $13 R \alpha 2$ is still unknown. Our observation that cell lines responsive to IL13 and IL4 did not express IL13R $\alpha 2$ (RCC and T98G glioma cell) and the results of Feng et al (1998) in synovial fibroblast cells raise the possibility that IL13R $\alpha 2$ acts as a dominant negative inhibitor or a decoy receptor for IL13. To assess this possibility, we constructed stably transfected IL $13 R \alpha 2^{+}$clones of the RCC cell line ACHN and compared their proliferative response with that of IL4 and IL13. Overexpression of IL13R $\alpha 2$ reduced the response to IL13 without affecting the response to IL4. This phenomenon was only observed at suboptimal IL13 concentrations (up to $5 \mathrm{ng} / \mathrm{ml}$ ), suggesting that the IL $13 \mathrm{R} \alpha 1 / \mathrm{IL} 4 \mathrm{R} \alpha \mathrm{com}$ plex on these cells remains functional. Our results demonstrate that IL $13 R \alpha 2$ acts as a membrane decoy receptor for IL13, but do not rule out the possibility that a soluble form of IL13R $\alpha 2$ is released into the supernatants of transfected cells. As described for the IL1 type II receptor (Bossù et al, 1995; Colotta et al, 1993), both membrane and soluble IL13R $\alpha 2$ could have antagonistic activities. A natural soluble form of IL13R $\alpha 2$ has been described in mouse serum and urine (Zhang et al, 1997). The protein sequence of this soluble form matches the $\mathrm{N}$ terminal part of the $\mathrm{mlL} 13 \mathrm{R} \alpha 2$ (Donaldson et al, 1998), suggesting that it is produced by proteolytic cleavage or alternative splicing. Recent data describe that alternative mRNA splicing of the murine IL13R $\alpha 1$ mRNA occurs, generating variant transcripts that encode sIL13R $\alpha 1$ (Osawa et al, 2000).

In conclusion, we demonstrate that IL $13 \mathrm{R} \alpha 2$ is overexpressed in glioma cells but not in RCC cells that expressed only one IL13R type composed of IL13R $\alpha 1$ and IL4R $\alpha$ chains. IL13R $\alpha 2$ overexpression correlates with a lack of sensitivity to IL13, suggesting that IL13R $\alpha 2$ acts as a decoy receptor for IL13. Through its expression, IL13R $\alpha 2$ may regulate IL13 activity without impairing the IL4 response of the same target cell.

\section{Materials and Methods}

\section{Cell Lines}

The RCC lines, ACHN and A704, were purchased from the American Type Culture Collection (Manassas, Virginia). IGR-RCC 1, 17, 40, 42, and 47 cell lines were obtained from Dr. E. Angevin (Institut GustaveRoussy, Villejuif, France) and are described in Angevin et al (1999). Glioma cell lines (SNB19, SF126, T98G, U399MG, U373MG, and SKMG12) were a gift from Dr. P. Horellou (INSERM EMI 00-20, Clamart, France). These cell lines were cultured in RPMI (RCC) or DMEM (glioma) supplemented with $10 \mathrm{~mm}$ HEPES, $100 \mathrm{U} / \mathrm{ml}$ penicillin, $100 \mu \mathrm{g} / \mathrm{ml}$ streptomycin, $1 \mathrm{~mm}$ sodium pyruvate, and 10\% heat-inactivated FCS (Gibco BRL, Paisley, Scotland). The cell lines were subcultured twice a week at $1 \times 10^{5}$ cells $/ \mathrm{ml}$.

\section{RNA Isolation and RT-PCR Analysis}

RNA extraction (from $5 \times 10^{6}$ cells) and cDNA preparation were previously described in Krzysiek et al (1999). cDNA (200 ng for $\beta$-actin, or $400 \mathrm{ng}$ for IL13R $\alpha 1$, IL13R $\alpha 2$, and IL4R $\alpha$ ) was amplified by standard PCR using IL13R $\alpha 1$ primers (sense: 5'-AGGATGACAAACTCGGAG, antisense: 5'-CTCAAGGTCCACAGTGAGGG) that amplified a product of $357 \mathrm{bp}$; IL4R $\alpha$ primers (sense: 5'-GACCTGGAGCAACCCGTATC, antisense: 5'-CATAGCACAACAGGCAGACG) that amplified a product of 335 bp (Reinecker and Podolsky, 1995); and IL13R $\alpha 2$ primers (sense: 5'ATACCTITGGGACCTATTCC3', antisense: 5'-TGAACATTTGGCCATGACTG3') that amplified a $428 \mathrm{bp}$ product. PCR conditions were 35 cycles of denaturation at $94^{\circ} \mathrm{C}$ for 1 minute, annealing at $58^{\circ} \mathrm{C}$ for 1 minute, and extension at $72^{\circ} \mathrm{C}$ for 2 minutes and 30 seconds (for IL13R $\alpha 1$ and IL13R $\alpha 2$ ), or annealing at $63^{\circ} \mathrm{C}$ for 50 seconds and extension at $72^{\circ} \mathrm{C}$ for 1 minute (for IL4R $\alpha$ ). IL13R $\alpha$ primers and PCR conditions were provided by Dr. P. Ferrara (Sanofi, Labège, France). Primers and PCR conditions for $\beta$-actin were described in Krzysiek et al (1999). Ten-microliter aliquots of amplified products were subjected to electrophoresis in $2 \%$ agarose gel stained with ethidium bromide. The gels were photographed under ultraviolet light, and bands were analyzed with FotoLook SA 2.0 software (AGFA-Gevaert, Munich, Germany).

\section{Production and Characterization of Anti-IL13Ra Chain Ab}

Monoclonal antibody E-74 raised against the IL13R $\alpha 1$ chain, a gift from Glaxo Wellcome (Stevenage, United Kingdom), was fully described in Graber et al (1998). Monoclonal antibody B-E34 raised against the IL13R $\alpha 2$ chain was a gift from Diaclone Research (Besançon, France) and was described in VermotDesroches et al (2000).

\section{Flow Cytometric Analysis of IL4Ro and IL13Ra Chain Expression}

Cells were detached from culture flasks by brief exposure to 1XPBS/4 mM EDTA. Cell surface staining was performed using the Enzymatic Amplification Staining Kit (Flow-Amp Systems, Ltd., Cleveland, Ohio) according to the manufacturer's recommendations. Cells $\left(5 \times 10^{5}\right)$ were incubated with mouse monoclonal antibodies (MoAbs) (10 $\mu \mathrm{g} / \mathrm{ml}$ ) directed to IL4R $\alpha$ (CD124, MB02, IgG2a; R\&D Systems, Inc., Abingdon, United Kingdom), IL13R $\alpha 2$ (CD213a2, B-E34, IgG1), $\gamma \mathrm{C}$ (CD132, TUGh4, IgG1; Pharmingen, San Diego, California), or IL13R $\alpha 1$ (CD213a1, E-74, IgG1). Mouse isotypematched IgG were used as controls. Immunostaining acquisition and analysis were performed on 
10,000 events gated on viable cells using a FACScan flow cytometer with CellQuest software (BD Biosciences, Franklin Lakes, New Jersey). Results are expressed as mean fluorescence intensity (MFI).

\section{Cell Lysates Preparation and IL13R 22 Protein Expression}

Confluent cells were washed and lysed as previously described (Rolling et al, 1995). Protein concentration was determined using a protein assay kit (BIO-RAD, Munich, Germany) according to the manufacturer's recommendations. Lysates were stored at $-80^{\circ} \mathrm{C}$ until tested. The presence of IL $13 R \alpha 2$ protein was detected by ELISA using different mAb CD213a2 (Diaclone SA, Besançon, France). Briefly, 96-well plates (Nunc, Roskilde, Denmark) were coated with 1 $\mu \mathrm{g} / \mathrm{well}$ of purified MoAb1 overnight at $4^{\circ} \mathrm{C}$. The plates were washed and blocked with $5 \%$ bovine serum albumin (Sigma Aldrich, Steinheim, Germany) for 2 hours at room temperature (RT). Then, $400 \mu \mathrm{g}$ of cell lysate samples or serial dilutions of standard recombinant IL13R $\alpha 2$-Fc (R\&D Systems) were added to wells and incubated at RT for 2 hours. After four washes in $0.5 \%$ Tween-20-PBS, $100 \mathrm{ng} /$ well of biotinylated MoAb2 was added, and the plates were incubated for 1 hour at RT. Following four washes, 100 $\mu$ l of avidin-horseradish peroxidase anti-mouse immunoglobulin was added, and the plates were incubated for 20 minutes at RT. Wells were then washed and TMB (Sigma) was added. The reaction was stopped with sulfuric acid $\left(\mathrm{H}_{2} \mathrm{SO}_{4}, 1 \mathrm{~N}\right)$ and read at $492 \mathrm{~nm}$ in a microtiter ELISA reader (DYNEX Technology, Chantilly, Virginia). The concentration of IL13R $\alpha 2$ in lysates was calculated by linear regression analysis from standard titration curves. Results are expressed as the mean concentration $(\mathrm{ng} / \mathrm{ml}, \pm \mathrm{SD})$ of triplicate determinations.

\section{Proliferation Assays}

Cells were seeded at $5 \times 10^{3}$ cells/well in 96-well microtiter plates (Costar, Cambridge, Massachusetts) and cultured in medium with 10\% FCS for two days and then for 3 days in the absence or in the presence of IL4 (Schering-Plough, Kenilworth, New Jersey), IL13 (R\&D Systems), or IL2 (Chiron, Amsterdam, The Netherlands) at various concentrations (see figure legends) in $200 \mu \mathrm{l}$ of medium with $2 \%$ FCS. For inhibition experiments, anti-IL4R $\alpha$ antibody (MOB2; R\&D Systems; $10 \mu \mathrm{g} / \mathrm{ml}$ ) was added 30 minutes before the cytokines, whereas SIL13R $\alpha 2-\mathrm{Fc}$ protein (R\&D Systems; $1 \mu \mathrm{g} / \mathrm{ml}$ ) was incubated with cytokines for 30 minutes before its addition to the cells. Proliferation was measured by supplying the culture with $0.5 \mu \mathrm{Ci} /$ well of (methyl- ${ }^{3} \mathrm{H}$ ) thymidine (Amersham, les Ulis, France) for the last 12 hours of the third day of culture. The plates were then frozen and thawed and the DNA was harvested onto a filtermat. Incorporated radioactivity was measured on a Wallac 1205 Betaplate counter (Wallac, Gaithersburg, Maryland) and results are expressed in counts per minute (cpm) (mean of triplicates $\pm \mathrm{SD})$.

\section{Transfection of ACHN Cells}

ACHN cells $\left(2 \times 10^{5}\right.$ cells/well) were plated in 6 -well culture plates (Costar) and cultured overnight. Ten micrograms of empty pSE1 vector or the vector containing the IL13R $\alpha 2$ cDNA were cotransfected with 1 $\mu \mathrm{g}$ of the selectable plasmid pSV40 containing the neomycin transferase cDNA by Lipofectamine (Gibco $B R L)$ according to the manufacturer's instructions. Neomycin-resistant transfectants were selected by inclusion of $800 \mu \mathrm{g} / \mathrm{ml}$ of active geneticin (Gibco BRL) in the cultures for 3 weeks. Selected cells were examined by flow cytometry to identify clones producing the IL13R $\alpha 2$ chain. Five such clones were identified and exhibited similar intensities of IL13R $\alpha 2$ immunoreactivity and similar results in proliferation experiments. Two of these clones, named 27 and 28 , are described in this paper. Clones transfected with the neomycin resistance vector and an empty vector (mock) were used as negative controls.

\section{Acknowledgements}

We thank P. Ferrara for the gift of IL13R $\alpha 2$ cDNA and A. Tsapis for helpful support. We also thank Glaxo Wellcome for the generous gift of anti-IL13R $\alpha 1$ antibody.

\section{References}

Aman MJ, Tayebi N, Obiri NI, Puri RK, Modi WS, and Leonard WJ (1996). cDNA cloning and characterization of the human interleukin 13 receptor alpha chain. J Biol Chem 271:2926529270.

Angevin E, Glukhova L, Pavon C, Chassevent A, TerrierLacombe MJ, Goguel AF, Bougaran J, Ardouin P, Court B-H, Perrin JL, Vallancien G, Triebel F, and Escudier B (1999). Human renal cell carcinoma xenografts in SCID mice: Tumorigenicity correlates with a poor clinical prognosis. Lab Invest 79:879-888.

Bossù $P$, Visconti $U$, Ruggiero $P$, Macchia G, Muda M, Bertini R, Bizzarri C, Colagrande A, Sabbatini V, Maurizi G, Del Grosso E, Tagliabue A, and Boraschi D (1995). Transfected type II interleukin-1 receptor impairs responsiveness of human keratinocytes to interleukin-1. Am J Pathol 147:18521861.

Caput D, Laurent P, Kaghad M, Lelias JM, Lefort S, Vita N, and Ferrara $P$ (1996). Cloning and characterization of a specific interleukin (IL)-13 binding protein structurally related to the IL-5 receptor alpha chain. J Biol Chem 271:1692116926.

Colotta F, Re F, Muzio M, Bertini R, Polentarutti N, Sironi M, Giri JG, Dower SK, Sims JE, and Mantovani A (1993). Interleukin-1 type II receptor: A decoy receptor for IL1 that is regulated by IL-4. Science 261:472-475.

Debinski W, Gibo DM, Hulet SW, Connor JR, and Gillespie GY (1999). Receptor for interleukin 13 is a marker and therapeutic target for human high-grade glioma. Clin Cancer Res 5:985-990.

Debinski W, Miner R, Leland P, Obiri NI, and Puri RK (1996). Receptor for Interleukin (IL) 13 does not interact with IL4 but receptor for IL4 interacts with IL13 on human glioma cells. J Biol Chem 37:22428-22433. 
Debinski W, Obiri NI, Powers SK, Pastan I, and Puri RK (1995). Human glioma cells overexpress receptors for interleukin 13 and are extremely sensitive to a novel chimeric protein composed of interleukin 13 and pseudomonas exotoxin. Clin Cancer Res 1:1253-1258.

Donaldson DD, Whitters MJ, Fitz LJ, Neben TY, Finnerty H, Henderson SL, O'Hara RM Jr, Beier DR, Turner KJ, Wood CR, and Collins M (1998). The murine IL13 receptor alpha 2: Molecular cloning, characterization, and comparison with murine IL13 receptor alpha 1. J Immunol 161:2317-2324.

Feng N, Lugli SM, Schnyder B, Gauchat JF, Graber P, Schlagenhauf E, Schnarr B, Wiederkehr-Adam M, Duschl A, Heim MH, Lutz RA, and Moser R (1998). The interleukin-4/ interleukin-13 receptor of human synovial fibroblasts: Overexpression of the nonsignaling interleukin-13 receptor $\alpha 2$. Lab Invest 78:591-602.

Gauchat JF, Schlagenhauf E, Feng NP, Moser R, Yamage M, Jeannin P, Alouani S, Elson G, Notarangelo LD, Wells T, Eugster HP, and Bonnefoy JY (1997). A novel 4-kb interleukin-13 receptor alpha mRNA expressed in human B, $\mathrm{T}$, and endothelial cells encoding an alternate type-II interleukin-4/interleukin-13 receptor. Eur J Immunol 27:971978.

Graber P, Gretener D, Herren S, Aubry JP, Elson G, Poudrier J, Lecoanet-Henchoz S, Alouani S, Losberger C, Bonnefoy JY, Kosco-Vilbois MH, and Gauchat JF (1998). The distribution of IL13 receptor alpha1 expression on B cells, T cells and monocytes and its regulation by IL13 and IL4. Eur J Immunol 28:4286-4298.

Hilton DJ, Zhang JG, Metcalf D, Alexander WS, Nicola NA, and Wilson TA (1996). Cloning and characterization of a binding subunit of the interleukin 13 receptor that is also a component of the interleukin 4 receptor. Proc Natl Acad Sci USA 96:497-501.

Joshi BH, Plautz GE, and Puri RK (2000). Interleukin-13 Receptor $\alpha$ chain: A novel tumor-associated transmembrane protein in primary explants of human malignant glioma. Cancer Res 60:1168-1172.

Kawakami K, Joshi BH, and Puri RK (2000). Sensitization of cancer cells to interleukin13-pseudomonas exotoxininduced cell death by gene transfer of interleukin 13 receptor $\alpha$ chain. Hum Gene Ther 11:1829-1835.

Krzysiek R, Lefevre EA, Zou W, Foussat A, Bernard J, Portier A, Galanaud P, and Richard Y (1999). Antigen receptor engagement selectively induces macrophage inflammatory protein-1 alpha (MIP-1 alpha) and MIP-1 beta chemokine production in human B cells. J Immunol 162:4455-4463.

Liu H, Jacobs BS, Liu J, Prayson RA, Estes ML, Barnett GH, and Barna BP (2000a). Interleukin-13 sensitivity and receptor phenotypes of human glial cell lines: Non-neoplastic glia and low-grade astrocytoma differ from malignant glioma. Cancer Immunol Immunother 49:319-324.

Liu J, Estes ML, Drazba JA, Liu H, Prayson R, Kondo S, Jacobs BS, Barnett GH, and Barna BP (2000b). Anti-sens oligonucleotide of p21 (waf1/cip1) prevents interleukin 4-mediated elevation of p27 (kip1) in low grade astrocytoma cells. Oncogene 19:661-669.

Maini A, Hillman G, Haas GP, Wang CY, Monticello E, Hamzavi F, Puntes JE, Leland P, Pastan I, Debinski W, and Puri RK (1997). Interleukin-13 receptors on human prostate carcinoma cell lines represent a novel target for a chimeric protein composed of IL13 and a mutated form of pseudomonas exotoxin. J Urol 158:948-953.

Miloux B, Laurent P, Bonnin O, Lupcker J, Caput D, Vita N, and Ferrara $P$ (1997). Cloning of the human IL-13R alpha1 chain and reconstitution with the IL4R alpha of a functional IL4/IL13 receptor complex. FEBS Lett 401:163-166.

Murata T, Obiri NI, Debinski W, and Puri RK (1997a). Structure of IL13 receptor: Analysis of subunit composition in cancer and immune cells. Biochem Biophys Res Commun 238:90-94.

Murata T, Obiri NI, and Puri RK (1997b). Human ovarian carcinoma cell lines express IL-4 and IL-13 receptors: Comparison between IL-4 and IL-13-induced signal transduction. Int J Cancer 70:230-240.

Murata T, Tagushi J, and Puri RK (1998). Interleukin-13 receptor alpha' but not alpha chain: A functional component of interleukin-4 receptors. Blood 91:3884-3891.

Obiri NI, Debinski W, Leonard WJ, and Puri RK (1995). Receptor for Interleukin13: Interaction with interleukin 4 by a mechanism that does not involve the common $\gamma$ chain shared by receptors for interleukins 2, 4, 7, 9 and 15. J Biol Chem 15:8797-8803.

Obiri NI, Husain SR, Debinski W, and Puri RK (1996). Interleukin 13 inhibits growth of human renal carcinoma cells independently of the p140 interleukin 4 receptor chain. Clin Cancer Res 2:1743-1749.

Obiri NI, Murata T, Debinski W, and Puri RK (1997). Modulation of interleukin (IL)-13 binding and signaling by the $\gamma \mathrm{c}$ chain of the IL-2 receptor. J Biol Chem 272:20251-20258.

Orchansky PL, Ayres SD, Hilton DJ, and Schrader WJ (1997). An interleukin (IL)-13 receptor lacking the cytoplasmic domain fails to transduce IL13-induced signals and inhibits responses to IL4. J Biol Chem 272:22940-22947.

Osawa M, Miyoshi S, Copeland NG, Gilbert DJ, Jenkins NA, Hiroyama T, Motohashi T, Nakamura Y, Iwama A, and Nakauchi $H$ (2000). Characterization of the mouse interleukin-13 receptor $\alpha 1$ gene. Immunogenetics 51:974-981.

Reinecker HC and Podolsky DK (1995). Human intestinal epithelial cells express functionnal cytokine receptors sharing the common gamma c chain of the interleukin 2 receptor. Proc Natl Acad Sci USA 92:8353-8357.

Rolling C, Treton D, Beckmann P, Galanaud P, and Richard Y (1995). Jak3 associates with the human interleukin 4 receptor and is tyrosine phosphorylated following receptor triggering. Oncogene 10:1757-1761.

Rolling C, Treton D, Pellegrini S, Galanaud P, and Richard Y (1996). IL4 and IL13 receptors share the $\gamma c$ chain and activate STAT6, STAT3 and STAT5 proteins in normal human B cells. FEBS Lett 393:53-57.

Serve H, Oelmann E, Herweg A, Oberbeg D, Serve S, Reufi B, Mucke C, Minty A, Thiel E, and Berdel WE (1996). Inhibition of proliferation and clonal growth of human breast cancer cells by interleukin 13. Cancer Res 56:3583-3588.

Smerz-Bertling C and Duschl A (1995). Both interleukin 4 and interleukin 13 induce tyrosine phosphorylation of the 140$\mathrm{kDa}$ subunit of the interleukin 4 receptor. J Biol Chem 270:966-970.

Tony HP, Shen Bo-J, Reusch P, and Sebald W (1994). Design of human interleukin 4 antagonists inhibiting interleukin 4 
dependent and interleukin 13-dependent responses in T cells and B cells with high efficiency. Eur J Biochem 225:659-665.

Vermot-Desroches C, Bonnin B, and Wijdenes J (2000). Identification and characterization of Abs anti-IL13R $\alpha 1$ or anti-IL13R $\alpha 2$. In Dupont B editors. Tissue Antigens 55:52-53.

Vita N, Lefort S, Laurent P, Caput D and Ferrara P (1995). Characterization and comparison of the interleukin-13 receptor with the interleukin-4 receptor on several cell types. J Biol Chem 270:3512-3517.

Welham MJ, Learmonth L, Bone H, and Schrader JW (1995). Interleukin-13 signal transduction in lymphohematopoietic cells. J Biol Chem 270:12286-12296.

Wills-Karp M, Luyimbazi J, Xu X, Schofield B, Neben TY, Karp CL, and Donaldson DD (1998). Interleukin-13: Central mediator of allergic asthma. Science 282:2258-2261.
Zhang JG, Hilton DJ, Willson TA, McFarlane C, Roberts BA, Moritz RL, Simpson RJ, Alexander WS, Metcalf D, and Nicola NA (1997). Identification, purification, and characterization of a soluble interleukin (IL)-13-binding protein. J Biol Chem 272:9474-9480.

Zurawski G and de Vries JE (1994). Interleukin 13, an interleukin 4-like cytokine that acts on monocytes and B cells, but not on T cells. Immunol Today 15:19-26.

Zurawski SM, Chomarat P, Djossou O, Bidaud C, McKenzie ANJ, Miossec P, Banchereau J, and Zurawski G (1995). The primary binding subunit of the human interleukin-4 receptor is also a component of the interleukin-13 receptor. $\mathrm{J}$ Biol Chem 270:13869-13878. 